\title{
EVE, THE EXISTING ABJECT \\ (Postmodern Feminist Study toward the Story of Adam and Eve in Bible)
}

\author{
Qurrota A'yunin \\ Gender Studies, University of Indonesia \\ qurrota.ayunin@ui.ac.id
}

\section{Abstract}

The search for human creation story is very interesting to discuss if it is viewed with a different perspective from mainstream story. The story of human creation is commonly called the story of Adam and Eve. Often, the story we hear is implicated in the marginalization of woman through Eve because she was created from Adam's ribs, and she was the cause of Adam's sin by eating fruit which was forbidden by God. The story is confirmed in the Bible so that it can give rise to biased interpretations. This study will offer another perspective in reading the stories of Adam and Eve written in the scriptures from Genesis 2 and 3. The postmodern feminist theory will be employed in rereading the figure of Eve in the Bible. The idea of this theory is that 'other' as a way to exist. Hence, the figure of Eve is attributed to the figure of 'other' who has the ability to exist. Analysis of this Eve figure will be focused on Julia Kristeva's view of the abject concept. Eventually, the concept of abject and 'other' stated in the postmodern feminist converged on the view that exclusion or non-existence is not entirely oppression which lead to the weakness figure. This is very closely related to the figure of Eve in the Bible so that the attribution in this study will lead to how Eve is seen as an existing abject. The result of this study reveals that Eve cannot be seen simply by focusing on her weaknesses by failing to maintain a commitment not to violate God's rules. Yet, her negligence becomes an opening for knowledge. Eve's negligence has manifested the world we currently live in as well. Holy books should be read with a variety of more egalitarian and unbiased perspectives so that gender justice can be realized without the pretext of religion as a barrier.

Keywords: Abject Concept; Adam and Eve Story; Julia Kristeva; Postmodern Feminist.

\section{INTRODUCTION}

One of the reflections on Liberal Feminist thinking is that he most essential human activities and separating them from animals is their capacity to think, imagine, and understand (Tong, 1998, p. 57). So, as human beings who are endowed with reason and 
rationality which are the distinguishing tools of other creatures of God, the search for human existence that does not exist into existence is an interesting thing to discuss, especially in academic spaces, equipped with analytical tools to enrich science and knowledge. The occurrence of human origins still needs to be further investigated do that it can become a wealth of discourses and counters of biased interpretations.

As the creation story in Genesis 2:20-23. That the first human was Adam (a man), while Eve (a woman) was created from Adam's ribs. Could inspire exegetists, poets, novelists, and even meme makers to publish various works and interpretations. As stated in the Old Testament Bible Commentary on the discussion of the creation of woman (2002, p. 38) said that:

"Perempuan berasal dari laki-laki, maka ia bergantung padanya. Bagian ini sering digunakan untuk mendukung pendapat bahwa perempuan lebih rendah dari laki-laki dan tunduk padanya ${ }^{1 . "}$

Moreover, among others, it can shift the view that it is as if humans, especially men, are biologically superior human beings, and women are the second human because they are created from male body parts. This has the potential to position women as 'other' that the existence in the world can be interpreted as not as complete as Adam's creation. Whereas, Genesis 3:12 about Eve's mistakes is very vulnerable to be interpreted to position women as a source of irregularities that caused Adam and herself to be expelled from the Garden of Eden (Heaven).

Departing from the potential problems above, I will show my opinion based on the thought of Julia Kristeva, a postmodern feminist, that Eve is the existing and the exalted 'other' (having existence as a subject or a complete self) in the Bible on Adam and Eve story, Genesis 2 and 3. Kristeva's theory that I use as an analysis knife is in the scope of postmodern feminist approach, which emphasizes discourse on language as the medium of idea. In the book entitled Feminist Thought (1998, p. 286), postmodern feminist use Beauvoir's understanding of 'other' and then they twist it. 'other' with all its relation to oppression and inferiority, is more than just an oppressed or inferior condition. 'other' is also a way of being, ways of thinking and ways of speaking that allow for openness, plurality, diversity, and difference. Whereas Abject, according to Kristeva (1982, p. 4) is "something rejected from which one does no part, from which one does not protect oneself as from an object". That is what disturbs identity, system, order, which does not respect boundaries, positions, and rules. Abject exclusion or expenditure is 'necessary' to maintain the subject's survival.

The previous study that concern in the interpretation of human creation story is written by Alin Roswantoro (2001) entitled 'Filsafat Manusia Muhammad 'Abduh (Studi Penafsiran Muhammad 'Abduh tentang Kisah Adam dalam Tafsir Al-Manar)'. Roswantoro only

\footnotetext{
${ }^{1}$ The interpreter in the book also denies the above understanding by saying, "Pasti ini bukan yang dimaksud oleh penulis. Tidak dapat disangkal bahwa perempuan tidak lebih rendah dari pada laki-laki. Dia diciptakan secara misterius oleh Allah memakai bahan dari manusia. Hal itu menggarisbawahi kesamaan sifat yang ia miliki dengan sifat laki-laki, dan juga menggarisbawahi ikatan yang ada diantara mereka. Bahwa, ia adalah "penolong" bagi laki-laki itu tidak menunjukkan kedudukannya yang lebih rendah".
} 
re-explained what Muhammad Abduh interpreted about the story of Adam. Gadamer's hermeneutics is used in rereading its interpretation. According to Roswantoro's writing, what is the substance of the human creation story according to 'Abduh is human (which is represented by the term Adam), while Devils and angels are accidents, they are not understood as people at all. Other rational interpretations are like Syajarah term which he understood symbolically as evil, not a physical tree. With a model of interpretation like this, he tries to show the basic philosophical character of humans, so that with understanding like this the Qur'an can actually be referred to really as guidance.

Other study that attempts to explicate the story of Adam and Eve is from Habibi Al Amin, M. Ag (2014) entitled 'Penciptaan Adam; Mendialogkan Tafsir Marah Labib dengan Teori Keadilan Gender'. In my opinion, Al Amin is not too keen to use gender justice theory because the results of his studies show something biased. He stated that the image of women was lower than that of men. For me, using Gender theory should focus on efforts to find gender justice in a text but what Amin did in his study only added to the existence of injustice in interpretation. What he called in the title of his study as a dialogue of interpretations and the theory of gender justice was not to dialogue but rather to judge that gender justice is not contained in the interpretation of the story of human creation.

From the above studies, most studies do not focus on other figures in the story of human creation. Another figure is Eve who always drowned and even interpreted it very unfairly. Eve became the other person who was not considered and was never seen with a positive perspective. Therefore, this study tries to find Eve who is often hidden and non-existent. The purpose of this study is to offer another view that the figure of Eve is a figure whose existence must be appreciated. In addition, this study also aims as a counter to biased interpretations in the story of Adam and Eve.

\section{THEORETICAL FRAMEWORK AND METHOD}

Postmodern feminism attempted to construct the social and cultural ideas about gender (Brown, 1997). They argue that woman is a socially defined and inherently distorted term. Postmodern feminist theory is free from prejudice and discrimination. They are aware about the oppression of women, process, empowerment, and the value of unity and personal experience (2004). Rockler (2006) has described that the young women should equipped for living fluidity of femininity in the postmodern world. Postmodern feminism embraces diversity and the coexistence of truths, roles, and realities. Thus, the focus is on female strengths rather than subjugation (Postmodern Feminism: A Theoretical Framework for a Field Unit with Woman in Jail, 2004).

According to Tong (2014, p. 192) postmodern feminists take de Beauvoir's understanding of otherness and turn it on its head. Woman is still the other, but rather than interpreting this condition as something to be transcended, postmodern feminists proclaim its advantages. The condition of otherness enables women to stand back and criticize the norms, values, and practices that the dominant culture (patriarchy) seeks to 
impose on everyone, including those who live on the periphery -in this case, women. Thus, otherness, for all of its associations with oppression and inferiority, is much more than an oppressed condition. It is also a way of being, thinking, and speaking allowing for openness, plurality, diversity, and differences. One of the easiest ways to understand postmodernism is to list the modernist (Enlightenment) beliefs it rejects. Jane Flax (1990, pp. 41-42) has provided a particularly good summary of the Enlightenment's main tenets, including the following:

1. There is a "stable, coherent self" that can know how and why it thinks the way it does.

2. Through its rational powers (reason), the self can gain "objective, reliable, and universal knowledge."

3. The knowledge that reason acquires is true; that is, it "represent[s] something real and unchanging (universal) about our minds and the structure of the natural world."

4. Reason has "transcendental and universal qualities"; that is, somehow reason exists independently of us viewed as historical beings situated in specific times and places.

5. Reason, freedom, and autonomy are interconnected in very complex ways. For example, if I am fully free, I will voluntarily obey the laws reason imposes on me. I will not rebel against the laws that bind me and all rational beings.

6. Power does not trump reason. On the contrary. Claims to power (authority) are grounded in reason. Therefore, when truth conflicts with power, reason steps in and decides the controversy in favor of truth.

7. The exemplar for all true knowledge is science understood as the "right use of reason." Science is neutral and objective in its methodology, and because this is so, it can utilize the laws of nature for our benefit.

8. Language, the tool we use to communicate the knowledge science produces, represents the real world that our rational minds observe. There is an isomorphic correspondence between word and thing. For example, the word "dog" corresponds to the entity, dog. Objects are not constructed by means of words or social conventions. Once perceived by our rational minds, objects are simply acknowledged by us through words.

Moreover, postmodern feminists desire to think non-binary, non-oppositional thoughts, the kind that may have existed before the Bible says Adam was given the power to name the animals, to determine the beginning and ends of things: "And out of the ground the Lord God formed every beast of the field, and every fowl of the air; and brought them unto Adam to see what he would call them - and whatsoever Adam called every living creature, that was the name thereof."(Genesis 2:19). We can imagine this original state prior to Adam's purported intrusion either as a Taoist undifferentiated "uncarved block," (Lao-tzu, 1962). As a Lacanian imaginary, as a Kristevian abject, or as any number of disordered conditions - the point being that there was, in the beginning, no word but only myriad voices waiting for time and space to interpret their meaning (2014, p. 208). 
Abject, according to Kristeva (1982, p. 4), is "something rejected from which one does no part, from which one does not protect oneself as from an object". This definition was then reiterated by Prabasmoro (2006, pp. 117-118) that Kristevian's abject is what disrupts identity, system, and who does not respect boundaries, positions, rules. Marginalization or removal of the object is needed to maintain the survival of the subject. Furthermore, abject relates to perversion because it is centered on the superego. Abject deviates because abject is not subject to prohibitions, rules or laws, the abject removes and ignores them.

The abjection of self would be the culminating form of that experience of the subject to which it is revealed that all its objects are based merely on the inaugural loss that laid the foundations of its own being. There is nothing like the abjection of self to show that all abjection is in fact recognition of the want on which any being, meaning, language, or desire is founded. One always passes too quickly over this word, "want," and today psychoanalysts are finally taking into account only its more or less fetishized product, the "object of want." But if one imagines (and imagine one must, for it is the working of imagination whose foundations are being laid here) the experience of want itself as logically preliminary to being and object-to the being of the object-then one understands that abjection, and even more so abjection of self, is its only signified. Its signifier, then, is none but literature (Kristeva, 1982).

Based on the theoretical framework above, the methodology I employ is descriptive qualitative feminist that empowerment is to make the object of study as subject. First, I classify the range of Adam and Eve stories stated in Genesis chapters 2 and 3. This makes it easier for the reader to understand the flow of the story presented in the Bible. Secondly, the analysis of Eve figure is reread in the best way offered by Kristeva. Finally, conclusion is drawn from findings based on postmodern feminist thought.

\section{DISCUSSION}

\section{Eve as an Existing Abject}

The searching that Eve is an Existing Abject must begin with a full reading of the range of stories presented in Genesis chapter 2 and 3. So, from the sequence and range of the story, we can identify the story comprehensively. I classify the range of the story of Adam and Eve as follows:

First, God created nature, heaven and earth and their contents.

Second, the creation of the first human.

Third, the creation of a garden as a place of shelter, called the Garden of Eden completed with plants, trees of life, and also trees called the trees of knowledge of good and evil. It is following with the command not to eat the fruit which is in the tree of knowledge, it is stated in Genesis 2:16-17 "And the Lord God commanded the man, "You are free to eat 
from any tree in the garden; but you must eat from the tree of knowledge of good and evil, for when you eat from it you will certainly die."'"

Fourth, the creation of the Adam pair, namely Eve, from Adam's ribs. This is stated in Genesis 2:23, "the man said, "this is now bone of my bones and flesh; she shall be called 'woman', for she was taken out of man"'

The last is the trickery of the snake in Eve to violate the command of God which caused her and Adam to be driven out of the Garden of Eden.

Adhering to what is described in the Interpretation of the New Testament Scriptures, Bergant and Karris (2002, p. 390) as editors say that the erroneous interpretation of the creation story in Genesis is: (1) because Eve was created after Adam, so in this context, wife must listen to the husband (although the two stories about the creation of Eve show their similarity with Adam: Gen. 1:27; 2:18, 23); (2) because Eve tempted Adam, then in the context of a conjugal relationship, the wife should not tease her husband again ". If you read the concept of Abject from Kristeva, it is precisely the position of Eve as 'other' and Abject who violates the rules and as not subject to prohibition because Eve has the authority to show the boundary between humans and animals, clean and dirty, proper and inappropriate by eating fruit from trees knowledge.

Thus, according to Krsteva, quoted by Prabasmoro (2006, p. 118), abjection also causes deviant pleasure. On the one hand, there is a desire to marginalize and ignore an object, on the other hand, there is pleasure as a subject who performs or is in the process of abjection to confront the object and then serve it. As sounded in Genesis 3: 1-7 (Alkitab Online),

\begin{abstract}
"Now the serpent was more crafty than any of the wild animals the LORD God had made. He said to the woman, "Did God really say, 'You must not eat from any tree in the garden'?" The woman said to the serpent, "We may eat fruit from the trees in the garden, but God did say, 'You must not eat fruit from the tree that is in the middle of the garden, and you must not touch it, or you will die."” "You will not certainly die," the serpent said to the woman. "For God knows that when you eat from it your eyes will be opened, and you will be like God, knowing good and evil." When the woman saw that the fruit of the tree was good for food and pleasing to the eye, and also desirable for gaining wisdom, she took some and ate it. She also gave some to her husband, who was with her, and he ate it. Then the eyes of both of them were opened, and they realized they were naked; so they sewed fig leaves together and made coverings for themselves."
\end{abstract}

Eve (Abject) which violates and deviates from the rule of God does not only show Eve's failure (who is as an object) in maintaining her commitment due to the deception of Snake, but, in the postmodern feminist view, Eve (who is also the subject) has shown that her violation is pleasure that can be attributed as an opening to rational reason and human 
knowledge. That, it was the female figure who "grabbed" the symbol of intellect symbolized by the fruit of the tree of knowledge of good and evil in Garden of Eden. Therefore, God is told in Genesis 3: 22,

"And the LORD God said, "The man has now become like one of us, knowing good and evil. He must not be allowed to reach out his hand and take also from the tree of life and eat, and live forever."

This Word of God, if it is read with the abject concept quoted in the introduction to this reflection, that the Subject will be compelled to get rid of abject so that the continuity of the Subject is maintained, is very attached to the figure of God. So, God sent Adam and Eve to earth to cultivate land and no longer easily maintain life by eating the fruit of the tree of life as it was available when they lived in the Garden of Eden. That is tied to what has been stated in Genesis 3: 23-24,

"So the LORD God banished him from the Garden of Eden to work the ground from which he had been taken. After he drove the man out, he placed on the east side of the Garden of Eden cherubim and a flaming sword flashing back and forth to guard the way to the tree of life."

\section{CONCLUSION}

The re-reading of the Story of Adam and Eve in the Bible that I tried to build with Kristeva-Postmodern Feminist's perspective is ultimately an attempt to see the hidden possibilities in the nothingness, absence, and deviation of the first female figure named Eve as the mother of all people. This possibility has shown that 'other' as well as Abject in Eve is her own way of being. Without Abundance of Eve, earth and humans may not function as they do today. In this point, I agree with what was written on the Catholic Faith website (Iman Katholik), assisted by Father F.X. Agus Triatmo O.Carm, that Adam and Eve's sin is a happy sin (Felix Culpa) because it has brought greater God's grace to mankind.

Biased interpretations are not supposed to be just silenced but those must be resisted by generating new interpretations and new views. It is merely so that the discourse presented does not become a rigid and indisputable thing. The narrative of human creation which is interpreted biased, in my opinion, not only in one or two religions, but there are many interpretations from various religions which still present a lame interpretation. Therefore, efforts to reread all religious texts are important. And, the most important thing is to bring out a woman as a subject rather than what the biased interpreter has been deliberately drowned in a patriarchal interpretation. 


\section{REFERENCES}

-. (n.d.). Iman Katholik. Retrieved from Media Informasi \& Sarana Katekese: https://www.imankatolik.or.id/kalender/24Des.html

Al-Amin, H. (2014). Penciptaan Adam; Mendialogkan tafsir Marah Labib dengan teori keadilan gender. An-Nuha vol.1 no.1, 1-26.

Alkitab Online. (n.d.). Retrieved from Alkitab Online Indonesia: http://alkitab.me/Kejadian/2\#.W_pJqvZuLIU

Brown, M. E. (1997). Feminism and cultural politics: Television audiences and Hillary Rodham Clinton . Political Communication 14 (2), 255-270.

Dianne Bergant, CSA. Robert J. Karris, OFM editor. (2002). Tafsir Alkitab perjanjian baru. penerj. A. S. Hadiwiyata, Lembaga Biblika Indonesia. Yogyakarta: Penerbit Kanisius.

Elizabeth C. Pomeroy, Lori K. Holleran \& Risa Kiam. (2004). Postmodern feminism: A theoretical framework for a field unit with woman in jail. Social Work Education: The International Journal Vol.23 (1), 39-49.

Flax, J. (1990). Postmodernism and gender relations in feminist theory, in feminism and postmodernism, ed. Linda Nicholson. New York: Routledge.

Kristeva, J. (1982). Powers of horror-an essay on abjection. Columbia: University Press.

Lao-tzu. (1962). "The Tao-te-Ching," in the texts of taoism, ed. James Legge. New York: Dover.

Noberthus Lede, E. D. (2002). Tafsir Alkitab perjanjian lama. Yogyakarta: Penerbit Kanusius.

Prabasmoro, A. P. (2006). Kajian budaya feminis: Tubuh, sastra, dan budaya pop . Yogyakarta: Jalasutra.

Rockler, N. R. (2006). "Be your own windkeeper": Friends, feminism, and rethorical strategies of depoliticization. Women's Studies in Communication Vol 29 (2), 244264.

Roswantoro, A. (2001). Filsafat manusia Muhammad 'Abduh (Studi penafsiran Muhammad 'Abduh tentang kisah Adam dalam tafsir al-Manar). Jurnal Studi Ilmu-Ilmu Al-Quran dan Hadis Vol 2 no.1, 17-34.

Tong, R. P. (1998). Feminist thought, penerj. Aquarini Priyatna Prabasmoro. Yogyakarta: Jalasutra.

Tong, R. P. (2014). Feminist thought: A more comprehensive introduction. Carolina: Westview Press. 